\title{
ANALISIS USAHA BUDIDAYA KEPITING BAKAU UNTUK MENINGKATKAN PENDAPATAN PEMBUDIDAYA TAMBAK DI KABUPATEN PANGKEP
}

\author{
Business Analysis Of Mud Crab Culture To Increase The Income Of Pond Farmers In Pangkep Regency
}

\author{
Vivi Imrona Fardiyah ${ }^{1}$, Andi Gusti Tantu ${ }^{2}$ dan Sri Mulyani ${ }^{2}$ \\ ${ }^{1}$ Dinas Perikanan dan Kelautan Kabupaten Pangkep, Sulawesi Selatam \\ ${ }^{2}$ Program Studi Budidaya Perairan Fakultas Pertanian Universitas Bosowa \\ Email : vivi20@yahoo.com
}

Diterima: 03 Februari 2021

Dipublikasikan: 15 Juni 2021

\begin{abstract}
ABSTRAK
Penelitian ini bertujuan untuk menganalisis pengaruh penggunaan input produksi terhadap hasil produksi, juga mengestimasi tingkat efisiensi penggunaan input produksi pada budidaya penggemukan kepiting bakau di Kabupaten Pangkep. Pada penelitian ini, teknik pengambilan sampel adalah sensus, yaitu petani pembudidaya penggemukan kepiting sebagai responden. Analisis data menggunakan Stochastic Production Frontier yang penyelesaiannya dengan bantuan program LIMDEP versi 6. Hasil estimasi menunjukkan dengan menggunakan fungsi produksi frontier bahwa variabel bebas yang signifikan berpengaruh positif terhadap produksi kepiting adalah luas keramba, jumlah benih dan jumlah pakan. Analisis terhadap Efisiensi Teknis (ET) rata-rata sebesar 0,94986. nilai tersebut dapat dikatakan sebagai prestasi atas kinerja penggunaan input produksi yang sangat memuaskan (mendekati 1), namun disisi lain kesempatan untuk melakukan pengembangan relatif sempit sehingga perlu upaya ekstensifikasi. Nilai R/C rasio sebesar 1,9516, artinya bahwa budidaya penggemukan kepiting bakau masih menguntungkan sehingga layak untuk dikembangkan.
\end{abstract}

Kata Kunci: Efisiensi, Kepiting Bakau, Return To Scale, R/C Rasio, Pangkep

\section{ABSTRACT}

His study aimed to analyze the effect of the use of inputs to production, also estimate the efficiency of use of production inputs in the cultivation of mangrove crab fattening in Pangkep. In this study, the sampling technique is the census that farmers crab fattening farmers as respondents. Analysis of data using Stochastic Production Frontier settlement with the help of the program LIMDEP version 6. The estimation results show using frontier production function that the independent variables were significant positive effect on the production of crab is spacious cages, seed number and amount of feed. Analysis of the Technical Efficiency (ET) by an average of 0.94986. The value can be regarded as the achievement of the performance use of production inputs very satisfying (approaching 1), but on the other hand the opportunity to develop a relatively narrow so that extending the necessary efforts. Rated $R$ / $C$ ratio of 1.9516, it means that the cultivation of mang rove crab fattening still profitable so as to develop.

Keywords: Crab, Efficiency, Return To Scale, R / C Ratio, Pangkep

\section{PENDAhUlUAN}

Potensi budidaya perikanan pantai di negara kita sangat besar, hal ini didukung oleh kenyataan bahwa sebagai negara kepulauan, Indonesia mempunyai panjang pantai lebih dari $81.000 \mathrm{~km}$, terdiri lebih dari 17.000 pulau tersebar luas antara $6^{\circ} \mathrm{LU}-11^{\circ} \mathrm{LS}$ dan $95^{\circ} \mathrm{BT}-141^{\circ} \mathrm{BT}, 70$ persen dari luas wilayahnya berupa laut (perairan) terbentang dari Sabang sampai Merauke. Di dalam wilayah Indonesia terkandung kekayaan hewani dan nabati yang saat ini tingkat eksploitasinya belum optimal. Sebagai negara bahari, bangsa Indonesia harus mampu memanfaatkan potensi perairan yang ada sebagai media penghubung antar pulau sekaligus sebagai sumber daya kehidupan maritim. Jika dimanfaatkan secara arif, potensi kekayaan tersebut dapat mendukung pembangunan sosial ekonomi menuju masyarakat Indonesia yang maju, makmur dan berkeadilan.

Namun potensi yang besar ini belum tergarap secara optimal sehingga membuka peluang bagi kita untuk mengelolanya (Departemen Pertanian, 1999). Sumber daya sektor perikanan saat ini memberikan kontribusi penting bagi perekonomian nasional antara lain:

1. Produk perikanan merupakan pemasok utama protein hewani bagi 250 juta lebih penduduk Indonesia

2. Sub sektor perikanan menyerap lapangan pekerjaan bagi sekitar 4,4 juta masyarakat nelayan/ petani ikan.

3. Penghasil devisa bagi perekonomian Indonesia Misi dan tujuan pembangunan sektor kelautan dan perikanan ke depan seyogyanya diarahkan untuk mencapai tiga target secara seimbang, yaitu:

a. meningkatkan pertumbuhan ekonomi dalam bentuk nilai ekspor, sumbangan terhadap PDB dan penyediaan lapangan kerja

b. pemerataan hasil-hasil pembangunan secara adil, terutama peningkatan kesejahteraaan masyarakat pesisir, nelayan dan petani ikan yang masih tertinggal

c. pemeliharaan daya dukung dan kualitas lingkungan.

Muara dari ketiga tujuan tersebut sudah barang tentu adalah peningkatan kesejahteraan segenap stakeholders (pihak terkait) sektor kelautan dan perikanan, dan dalam kerangka 
mewujudkan masyarakat Indonesia yang maju, makmur dan berkeadilan. Khusus perihal kesejahteraan masyarakat nelayan, utamanya di daerah pesisir, banyak faktor yang menyebabkan mereka masih tertinggal, mulai dari faktorfaktor yang berkaitan dengan sumber daya alam yang semakin menipis, budaya kurang dapat menabung dan kurang dapat mengelola keuangan keluarga, sampai struktur ekonomi (tata niaga) yang belum kondusif bagi kemajuan dan kemakmuran para nelayan kita (Dahuri, 2001).

Mangrove atau bakau merupakan tumbuhan yang unik dan menarik karena dapat tumbuh dengan baik ditempat yang tergenang pada waktu pasang dan di tempat yang kering pada waktu air laut surut. posisinya yang unik menempatkannya sebagai salah satu mata rantai ekosistem darat dan laut. Salah satu fungsinya yang penting adalah sebagai sumber energi dan zat hara bagi kehidupan estuari atau perairan pantai, dengan kata lain bakau dapat meningkatkan kesuburan perairan pantai di sekitarnya.

Hutan bakau selain berfungsi sebagai sabuk hijau (green belt) yang melindungi pantai dari abrasi air laut, juga mempunyai fungsi ekologis penting bagi sumber daya perikanan pantai (Budi et al, 2017; Budi et al, 2020). Hal ini disebabkan karena hutan bakau di wilayah pantai merupakan sumber produktivitas primer, tempat bermulanya rantai ekosistem bagi biota air maupun biota lainnya untuk mencari makan (feeding ground). Selain itu juga berfungsi sebagai tempat berlindung atau daerah asuhan (nursery ground) karena lebatnya daun dan perakaran yang unik dan kuat. Disisi lain, habitat bakau dapat menjadi tempat untuk pemijahan (spawning ground), yang sangat cocok untuk berbagai kehidupan biota atau komoditas perikanan (Budi et al, 2018).

Salah satu komoditas perikanan yang mempunyai nilai ekonomis tinggi dan dapat dikembangkan disini adalah jenis kepiting bakau (Scylla serrata) (Departemen Pertanian, 1999).

Kepiting bakau (scylla serrata) merupakan satu diantara komoditas laut yang mempunyai nilai ekonomis tinggi di pasaran dunia. Sangat digemari konsumen lokal maupun luar negeri dan dalam kurun waktu sepuluh tahun terakhir ekspor kepiting meningkat rata-rata $14,06 \%$. Komoditas ini mempunyai kandungan nilai gizi tinggi, protein dan lemak, bahkan pada telur kepiting kandungan proteinnya sangat tinggi, yaitu sebesar $88,55 \%$. Dengan nilai komposisi demikian, komoditas ini sangat digemari konsumen luar negeri dan menjadi salah satu makanan paling bergengsi di kalangan mereka. Amerika Serikat merupakan negara penyerap hampir 55\% produksi kepiting dunia, sedang permintaan lainnya datang dari negara-negara di kawasan Eropa, Australia, Jepang, Hongkong, Taiwan, Singapura, Korea Selatan (Ditjen Perikanan, 2010).

Permintaan ekspor kepiting bakau terus meningkat dan telah menjadikan komoditas ini sebagai salah satu andalan ekspor non migas yang pada tahun 2010 meraup devisa US \$ 35.298.000 (Ditjen Perikanan, 2010). Namun kebutuhan ekspor kepiting bakau selama ini masih mengandalkan hasil penangkapan di alam/ kawasan bakau yang apabila eksploitasi kepiting bakau ini semakin intensif dan tidak terkendali akan mengancam kelestarian sumber daya tersebut. Oleh karena itu, guna memenuhi kebutuhan konsumsi domestik maupun kebutuhan ekspor yang terus meningkat diperlukan upaya alternatif melalui usaha budidaya.

Upaya budidaya, yaitu penggemukan kepiting bakau telah cukup berkembang yang dilakukan oleh petani tambak di Indonesia. Di beberapa daerah di Sulawesi Selatan, usaha ini dilakukan dengan sistem silvofishery, yang memadukan antara budidaya komoditas perikanan berupa ikan bandeng dan kepiting dengan penanaman tanaman bakau. Hal ini menjadi salah satu alternatif bagi para petani tambak atas kegagalan mereka dalam budidaya udang windu beberapa tahun terakhir.

Budidaya penggemukan kepiting bakau ini berkembang di beberapa daerah antara lain di Kabupaten Maros, Pangkep, Barru dan beberapa daerah di pesisir Teluk Bone. Hal ini karena kepiting bakau cenderung mudah untuk dipelihara, lebih tahan terhadap kondisi perubahan lingkungan dan dapat dilakukan dengan teknologi yang sederhana dan mudah sekalipun oleh petani pemula.

\section{METODE PENELITIAN}

\section{a. Jenis dan Sumber Data}

Jenis data yang dipakai dalam penelitian ini adalah data primer dan data sekunder. Data primer diambil secara cross section dari satu kali proses produksi yang diperoleh melalui wawancara secara langsung dari responden sampel serta menggunakan daftar pertanyaan. Data sekunder merupakan data-data penunjang dalam penelitian ini yang diperoleh dari lembaga atau instansi yang terkait dalam penelitian ini, antara lain BPS Sulawesi Selatan, BPS Kabupaten Pangkep, Dinas Kelautan dan Perikanan Provinsi Sulawesi Selatan dan Dinas Perikanan Kabupaten Pangkep.

b. Teknik Pengumpulan Data

Teknik pengumpulan data dalam penelitian ini adalah dengan wawancara dan dokumentasi. Yang dimaksud dengan wawancara adalah proses memperoleh keterangan untuk tujuan penelitian dengan cara tanya jawab sambil bertatap muka antara si penanya dan atau pewawancara dengan si penjawab atau responden dengan menggunakan alat yang dinamakan interview guide (panduan wawancara).

Teknik wawancara dilakukan dengan bantuan pedoman daftar pertanyaan. Teknik dokumentasi adalah dengan mengumpulkan data-data yang berkaitan dengan penelitian baik dari instansi terkait maupun media cetak dan internet.

c. Populasi

Populasi (Universe) ialah jumlah keseluruhan dari unit analisa yang ciri cirinya akan diduga (Dajan, 1996; Singarimbun dkk, 1989). Populasi dalam penelitian ini adalah meliputi seluruh petani budidaya penggemukan kepiting bakau di Kabupaten Pangkep yang berjumlah 37 pembudidaya yaitu yang berlokasi di Kecamatan Labakkang (Desa Borimasunggu, Kelurahan Pundata Baji, Desa Bontomanai, dan Desa Kanaungan). Pada penelitian ini, metode yang digunakan adalah sensus.

d. Teknik Analisa Data

Teknik analisa data yang dipergunakan untuk menganalisis faktor-aktor yang mempengaruhi efisiensi produksi budidaya 
penggemukan kepiting bakau yang diamati adalah dengan memakai fungsi produksi Cob-Douglas dan Fungsi produksi frontier (Stochastic Production Function Cob-Douglas) (Zen, et. Al., 2003; Panayotou, 1980

Metode analisis statistik deskriptif juga digunakan dalam penelitian ini yaitu untuk menghitung indikator sosialekonomi seperti profil responden, misalnya umur, jumlah anggota keluarga, tingkat pendidikan, dan lain-lain (Susilowati, 1997). Analisis deskriptif juga digunakan untuk mengetahui gambaran umum dan kondisi usaha nelayan dan pengolahan ikan di daerah penelitian yang meliputi jumlah produksi, penerimaan total dan biaya total, serta keuntungan yang diperoleh.

\section{HASIL DAN PEMBAHASAN}

Hasil penelitian menunjukkan bahwa total jumlah responden yang berhasil diwawancarai sejumlah 37 orang petani / pembudidaya penggemukan kepiting bakau yang tersebar di empat desa/kelurahan dalam wilayah kecamatan Labakkang, yaitu: Desa Borimasunggu, Kelurahan Pundata Baji, Desa Bontomanai, dan Desa Kanaungan.

Berdasarkan hasil estimasi dapat dijelaskan bahwa faktorfaktor yang berpegaruh sangat nyata terhadap produksi penggemukan kepiting bakau pada daerah penelitian adalah variabel luas keramba $\left(\mathrm{LX}_{1}\right)$, Jumlah Benih $\left(\mathrm{LX}_{2}\right)$ dan Jumlah Pakan $\left(\mathrm{LX}_{3}\right)$ dengan tingkat signifikasi dengan $\alpha=1 \%$. Sedangkan secara statistik faktor lainnya yaitu tenaga kerja $\left(\mathrm{LX}_{4}\right)$ belum mampu berpengaruh secara signifikan terhadap produksi kepiting bakau. Sementara itu variabel internal yang berpengaruh secara signifikan terhadap in-efisiensi adalah tingkat pendapatan responden $\left(\mathrm{LZ}_{1}\right)$ dengan tingkat signifikasi dengan $\alpha=5 \%$. Sementara variabel internal yang lain seperti tingkat pendidikan dan umur responden secara statistik belum memberikan pengaruh yang signifikan.

Dalam penelitian ini koefisien variabel eksternal yang berpengaruh terhadap fungsi produksi yang meliputi luas lahan $\left(\mathrm{LX}_{1}\right)$, Jumlah Benih $\left(\mathrm{LX}_{2}\right)$, dan Jumlah Pakan $\left(\mathrm{LX}_{3}\right)$, mempunyai tanda yang positif. Hal ini dapat diartikan bahwa penambahan faktor-faktor produksi tersebut akan mampu meningkatkan produksi yang dihasilkan. Dengan kata lain perluasan areal keramba, penambahan jumlah benih dan juga penambahan jumlah pakan akan mampu meningkatkan produksi kepiting bakau. Sementara itu koefisien variabel tenaga kerja bertanda negatif yang dapat diartikan bahwa penambahan input tenaga kerja ternyata akan mengurangi produksi yang dihasilkan. Hal ini dapat dipahami mengingat pekerjaan penggemukan kepiting bakau dalam jumlah dan luas lahan tertentu tidak membutuhkan banyak tenaga kerja, cukup dikerjakan sendiri bersama dengan anggota keluarga yang lain sehingga mampu menghemat biaya tenaga kerja.

Seperti yang telah dikemukakan pada diatas, bahwa lahan dalam hal ini keramba mempunyai peranan yang sangat penting dalam proses produksi penggemukan kepiting bakau. Luas keramba mempunyai hubungan yang positif dengan produksi, yang artinya bila luas keramba ditingkatkan atau diperluas dalam jumlah tertentu maka diharapkan akan dapat meningkatkan produksi kepiting bakau secara maksimal. Nilai koefisien estimasi sebesar 0,1514 mengindikasikan bila ada penambahan luas keramba sebanyak satu persen maka diharapkan akan dapat meningkatkan produksi kepiting bakau sebesar 0,15 persen.

Kedua variabel ini, baik jumlah benih maupun jumlah pakan juga mempunyai nilai koefisien estimasi yang positif yaitu sebesar 0,52680 sehingga hubungan dengan produksi kepiting bakau juga positif. Kedua variabel ini mempunyai nilai koefisien yang sama mengingat bila ada penambahan jumlah benih maka secara otomatis harus ada penambahan jumlah pakan yang diberikan. Benih dan pakan dalam proses produksi kepiting bakau memiliki aturan ataupun standar baku sehingga porsi benih dan pakan akan selaras.

Variabel ini ternyata secara statistik tidak berpengaruh secara signifikan dalam proses produksi, disamping itu nilai koefisien juga negatif yang mengindikasikan hubungan berbanding terbalik dengan proses produksi. Dalam penelitian ini populasi dari petani tambak yang ada masih dalam skala usaha kecil yang terbatas pada faktor-faktor produksi seperti lahan, benih dan pakan yang terbatas pula. Untuk itu kegiatan operasional dalam proses penggemukan kepiting bakau masih dapat ditangani secara mandiri tanpa perlu membutuhkan banyak tenaga kerja.

Pada fungsi "U" (inefficiency function) dari 3 variabel yaitu : tingkat pendapatan responden, usia/umur responden, dan tingkat pendidikan formal yang dimiliki oleh responden yang dihipotesiskan merupakan determinan in-efisiensi terdapat satu variabel yang ikut berpengaruh terhadap inefisiensi produksi kepiting bakau yaitu variabel tingkat pendapatan.

Variabel ini secara statistik berpengaruh nyata terhadap inefisiensi produksi kepiting bakau. Tingkat pendapatan merupakan proksi dari ukuran ekonomi rumah tangga yang berkorelasi positif dengan kemampuan pembudidaya kepiting bakau dalam menyediakan modal untuk pengembangan usaha budidaya kepiting bakau. Fenomena ini merupakan bukti empiris bahwa meningkatnya kemampuan pembudidaya dalam membiayai usaha budidaya sangat kondusif untuk meningkatkan efisiensi teknis usaha budidayanya. Dengan meningkatnya kemampuan permodalan maka makin mudah bagi petani pembudidaya penggemukan kepiting bakau untuk memperoleh masukan (input) dengan mutu yang lebih baik dan tepat waktu.

Variabel ini diasumsikan menggambarkan pengalaman responden berkecimpung dalam proses produksi kepiting bakau. Hampir semua responden mempunyai latar belakang sebagai petani tambak yang dahulunya membudidayakan bandeng. Pengalaman-pengalaman mereka dalam usaha budidaya akan dapat dikembangkan dan dapat diaplikasikan dalam budidaya penggemukan kepiting bakau sehingga diharapkan dapat memberikan nilai tambah dalam proses produksi. Namun variabel ini secara statistik belum berpengaruh terhadap proses produksi.

Tingkat pendidikan merupakan gambaran kondisi sosial dari responden. Sebagian besar responden meempunyai tingkat pendidikan yang relatif rendah (Sekolah Dasar) sehingga pemahaman akan fungsi produksi, produktivitas serta kinerja juga dirasa masih lemah. Petani tambak lebih mengandalkan insting dan intuisi dalam upaya pembudidayaan, sementara masukan-masukan yang bersifat keilmuan akan susah dipahami. Hal ini menjadikan secara statistik tingkat 
pendidikan tidak berpengaruh terhadap produksi kepiting bakau di daerah penelitian. Usaha penggemukan kepiting bakau dapat dikatakan masih dapat ditingkatkan produksinya, dimungkinkan dengan penambahan input tertentu, maka produksi kepiting diharapkan juga akan meningkat seperti dicerminkan dari nilai return to scale (RTS) nya lebih besar dari 1 yaitu sebesar 1,1758 .

Dari 37 responden petani pembudidaya penggemukan kepitig bakau yang diteliti, rata-rata efisiensi teknisnya (TE) adalah sebesar 0,94986 . Artinya, rata-rata produktivitas yang dicapai adalah sebesar $94,98 \%$ dari frontier, yakni produktivitas maksimum yang dapat dicapai dalam proses produksi. Tingkat efisiensi teknis yang dapat dikatakan sangat tinggi ini dapat diinterprestasikan berwajah ganda (ambivalent). Di satu sisi, tingkat efisiensi teknis yang tinggi mencerminkan prestasi atas terpakainya hampir seluruh sumber daya (faktor produksi) secara optimal. Penggunaan input-input produksi seperti luas lahan, benih, pakan, dan tenaga kerja mempengaruhi produksi pada level yang sangat memuaskan. Namun di sisi lain, tingkat efisiensi teknis yang tinggi juga merefleksikan bahwa peluang untuk pengembangan lebih lanjut agar tercapai produktivitas yang tinggi sangat kecil mengingat senjang antara tingkat produktivitas yang telah dicapai dengan tingkat produksi maksimum sangat sempit (gambar 1).

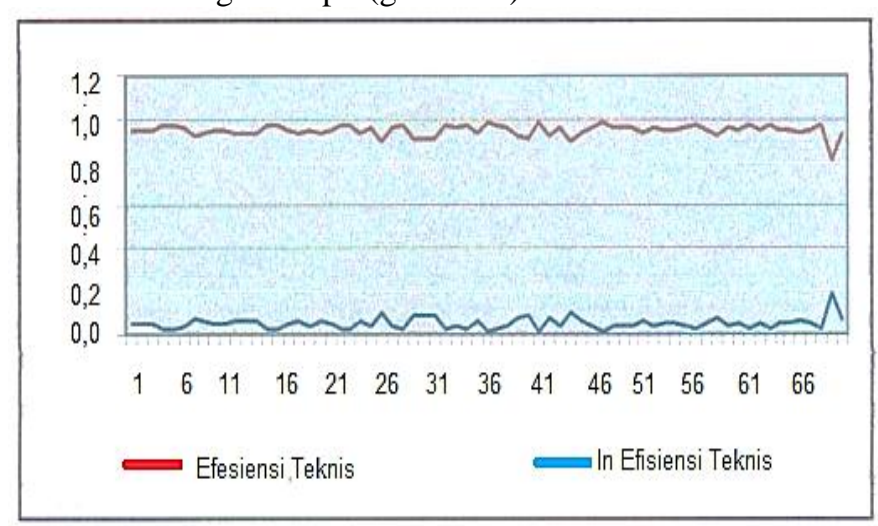

Gambar1. Grafik Tingkat Efisiensi dan Inefisiensi Produksi Kepiting Bakau

Tingkat produksi yang semacam ini, dimana masih ada ruang untuk penambahan input yang mampu menghasilkan tambahan output yang lebih besar karena RTS-nya lebih dari 1, maka harus ada upaya ektensifikasi yaitu dengan pembuatan lahan baru. Indikator lain yang menunjukkan bahwa ektensifikasi adalah kebijakan yang tepat untuk peningkatan produksi adalah rata-rata produksi aktualnya (QY) adalah $87,39577 \mathrm{~kg}$, sementara perkiraan produksi potensialnya (QQ) dalam jangka panjang adalah sebesar 87,27536 kg. Hal ini mengindikasikan bahwa produksi aktual sudah melebihi kapasitas (potensi) produksinya. Bila hal ini diteruskan dapat mengakibatkan keadaan produksi yang semakin menurun.

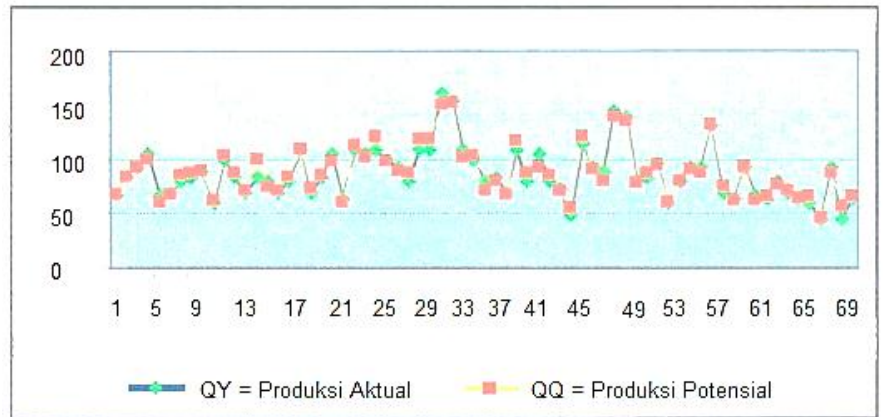

Gambar 2. Grafik Produksi Aktual dan Potensial Kepiting Bakau

Gambar 2 memperlihatkan bahwa secara individu, tingkat efisiensi teknis dan in-efisiensi teknis dari responden yang diamati $(n=69)$ adalah bervariasi namun nilainya hampir mendekati angka 1 .

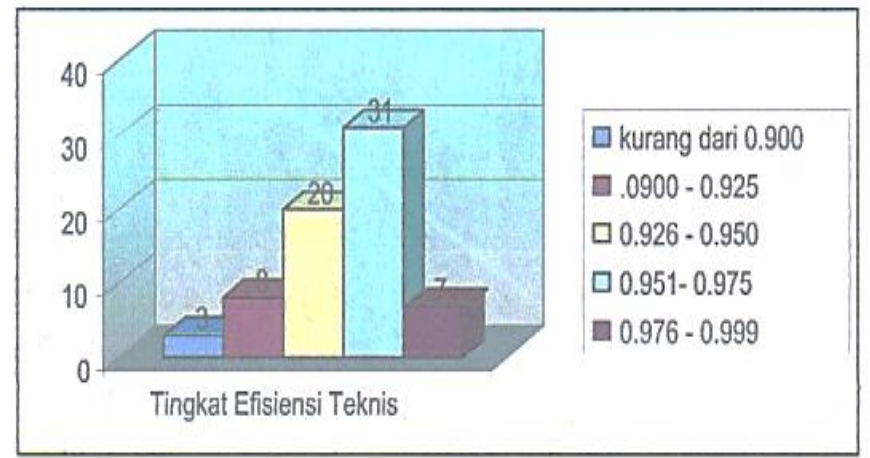

Gambar 3. Frekuensi Tingkat Efisiensi Teknis Produksi Kepiting Bakau

Ternyata efisiensi teknis produksi kepiting bakau, hampir seluruh responden $(\mathrm{n}=37)$ sudah mencapai $90 \%$ ke atas yang mencapai 36 responden atau sekitar 95\% dari total responden yang ada. Dengan demikian sebenarnya penggunaan variabel input dalam proses produksi kepiting bakau ini sudah hampir mendekati efisien. Sebaran dari nilai efisiensi teknis dapat dilihat dalam Tabel 1.

Tabel 1. Sebaran Tingkat Efisiensi Teknis

\begin{tabular}{lccc}
\hline \multicolumn{1}{c}{ Luas Keramba } & Frekuensi & Persentase & $\begin{array}{c}\text { Mean } \\
\text { TE }\end{array}$ \\
\hline kurang dari $8 \mathrm{~m} 2$ & 14 & 20.29 & 0,95 \\
$8-10 \mathrm{~m} 2$ & 34 & 49.28 & 0,95 \\
$11-13 \mathrm{~m} 214 \mathrm{~m} 2 \mathrm{ke}$ & 9 & 13.04 & 0,96 \\
atas & 12 & 17.39 & 0,94 \\
\hline
\end{tabular}

Sumber : Data Primer, 2020

Tingkat efisiensi teknik yang dilihat dari sebaran berdasar klasifikasi luas keramba pada daerah penelitian, dapat dinyatakan bahwa jumlah luas keramba yang dimiliki oleh petani tambak yang paling efisien adalah berkisar antara 11 $14 \mathrm{~m}^{2}$ dengan tingkat efisiensi rata-rata sebesar 0,95 . Namun secara keseluruhan tingkat efisiensi yang dicapai dari seluruh responden sangat tingi.

Tingkat efisiensi harga ditunjukkan oleh besarnya Nilai Produk Marginal (NPM). Efisien dapat diartikan sebagai upaya penggunaan input tertentu untuk mendapatkan produksi 
yang maksimal. Dengan kata lain, mampu membuat NPM untuk suatu input sama dengan harga input (P) itu sendiri (=1). Tetapi dalam kenyataanya, NPMx tidak selalu sama dengan Px. Yang sering terjadi bahkan (NPMx/Px) lebih besar atau lebih kecil daripada satu. Bila lebih besar dari satu disebut belum efisien, sehingga perlu menambah input untuk dapat mencapai efisien. Sedangkan apabila nilai NPM lebih kecil daripada satu, maka situasi ini menunjukkan penggunaan input yang tidak efisien. Sehingga untuk menjadi efisien, maka penggunaan input perlu dikurangi (Soekartawi, 2003). Nilai NPM disini diperoleh dari nilai koefisien masing-masing variabel dikalikan dengan rata-rata biaya total dibagi dengan rata-rata biaya dari masing-masing variabel tersebut. Efisiensi ekonomi juga merupakan produk dari efisiensi Teknik dan Efisiensi Harga, sehingga Efisiensi Ekonomi dapat dirumuskan sebagai berikut (Susantun, 2000) :

$$
\mathrm{EE}=\mathrm{ET} \times \mathrm{EH}
$$

Di mana :

$\mathrm{EE}=$ Efisiensi Ekonomis

$\mathrm{ET}=$ Efisiensi Teknis

$\mathrm{EH}=$ Efisiensi Harga

Dalam penelitian ini variabel input yang diamati dalam analisis efisiensi arga adalah luas keramba $\left(\mathrm{X}_{1}\right)$, benih $\left(\mathrm{X}_{2}\right)$, pakan $\left(\mathrm{X}_{3}\right)$ dan tenaga kerja $\left(\mathrm{X}_{4}\right)$. Hasil analisis efisiensi harga untuk usaha penggemukan kepiting bakau dapat dilihat pada Tabel 1. Pada tabel tersebut terlihat bahwa penggunaan input tidak sama dengan satu yaitu sebesar 8,2824 artinya bahwa penggunaan input tidak efisien atau belum mencapai efisien harganya, sehingga masih dimungkinkan dilakukan penambahan input atau penurunan harga input tertentu. Dari Tabel 1 dapat perbandingkan bahwa input yang belum efisien dan perlu ditambahkan masing-masing adalah bahan luas keramba dengan rasio 4,0654, jumlah pakan dengan rasio 3,9442 Sedangkan yang tidak efisien dan perlu pengurangan input adalah jumlah benih dengan rasio 0,7957 dan tenaga kerja dengan rasio 0,5229 artinya benih dan tenaga kerja berlebihan sehingga perlu dikurangi.

Tabel 2. Nilai Efisiensi Harga dan Efisiensi Ekonomis

\begin{tabular}{|c|c|c|c|c|c|}
\hline \multicolumn{2}{|l|}{ Koef. } & \multicolumn{2}{|c|}{$\begin{array}{c}\text { Rasio Nilai } \\
\text { Produk Marginal } \\
\text { (NPM) }\end{array}$} & \multicolumn{2}{|c|}{ Efisiensi } \\
\hline$\beta 1$ (Luas Keramba) & 0,1514 & NPM1 & 4,0654 & $\mathrm{EH}$ & 8,2824 \\
\hline$\beta 2$ (Benih) & 0,5268 & NPM2 & 0,7957 & ET & 0,9499 \\
\hline$\beta 3$ (Pakan) & 0,5268 & NPM3 & 3,9442 & $\mathrm{EE}$ & 7,8674 \\
\hline$\beta 4$ (Tenaga Kerja) & $-0,0874$ & NPM4 & $-0,5229$ & & \\
\hline
\end{tabular}

Sumber: Data Primer Diolah, 2020

Berdasarkan efisiensi teknis (ET) dan efisiensi harga $(\mathrm{EH})$ maka diperoleh nilai efisiensi ekonomis usaha budidaya penggemukan kepiting bakau sebesar 7,8674. Oleh karena efisiensi ekonomis lebih besar dari 1, maka dapat disimpulkan bahwa usaha budidaya penggemukan kepiting bakau masih memungkinkan untuk dikembangkan. Untuk mencapai efisien secara keseluruhan perlu adanya penambahan input-input tertentu yang masih dimungkinkan untuk ditambahkan sehingga diharapkan penggunaan input yang efisien ini akan menghasilkan produksi kepiting bakau yang optimal. Petani budidaya penggemukan kepiting bakau harus mampu mengelola dan mengalokasikan faktor-faktor/input produksi secara efektif dan efisien.

Penerimaan dan pengeluaran usaha budidaya kepiting bakau dalam setiap kali proses produksi meliputi penerimaan atas hasil produksi yang diperoleh. Kepiting bakau berjenis kelamin betina dihargai lebih tinggi dibandingkan kepiting jantan. Harga kepiting betina mencapai Rp 80.000,- per kilogram, sementara kepiting jantan lebih murah yaitu Rp 60.000.- per kilogram.

Tabel 3. Rata-rata Penerimaan dan Pengeluaran dalam Proses Produksi

\begin{tabular}{lcccc}
\hline \multicolumn{1}{c}{ Ket. } & $\begin{array}{c}\text { Min. } \\
(\text { x.000) }\end{array}$ & $\begin{array}{c}\text { Max. } \\
(\text { x.000) }\end{array}$ & $\begin{array}{c}\text { Mean } \\
(\text { x.000) }\end{array}$ & $\begin{array}{c}\text { Std. } \\
\text { Deviation }\end{array}$ \\
\hline Penerimaan & 1540 & 5520 & 2888115,9420 & 796579,5912 \\
\hline Biaya-biaya & & & & \\
- Benih & 320 & 1856 & 979710,1449 & 346003,9570 \\
- Pakan & 105 & 350 & 197644,9275 & 59264,6173 \\
- Keramba & 112,5 & 375 & 247334,3478 & 62319,3954 \\
- Tenaga Kerja & 25 & 105 & 55108,6957 & 16679,4761 \\
Biaya Total & 632 & 2673,5 & 1479798,1159 & 425189,0028 \\
\hline Keuntungan & 507,5 & 2846,5 & 1408317,7971 & 544482,8672 \\
\hline R/C RASIO & & & 1,9516 & \\
\hline
\end{tabular}

Komponen biaya dalam budidaya kepiting bakau meliputi biaya pembelian benih, pembelian pakan, biaya penyiapan lahan dan keramba serta biaya untuk tenaga kerja. Dalam satu kali proses produksi rata-rata pos pengeluaran untuk pembelian benih mencapai Rp 1.879.710,14 sedangkan untuk pembelian pakan mencapai Rp 367.644,93. Alokasi anggaran untuk pembuatan dan persiapan lahan berupa keramba dan perangkatnya rata-rata mencapai $\mathrm{Rp} 537.334,35$ dan biaya untuk tenaga kerja dalam budidaya kepiting bakau sebesar Rp 110.108,70. Rata-rata hasil yang diperoleh setelah panen mencapai Rp 4.657.115,94 sedangkan untuk pengeluaran total mencapai Rp 2.849.798,12 sehingga diperoleh keuntungan rata-rata sebesar $\mathrm{Rp} 2.798 .317,80$. Perbandingan antara pengeluaran total dengan penerimaan total diperoleh nilai $\mathrm{R} / \mathrm{C}$ ratio sebesar 1,9516. Hal ini membuktikan bahwa usaha budidaya penggemukan kepiting bakau masih cukup menguntungkan.

\section{KESIMPULAN DAN SARAN}

Hasil penelitian menunjukkan bahwa estimasi dengan menggunakan fungsi produksi frontier dapat dinyatakan bahwa variabel bebas yang signifikan berpengaruh positif terhadap produksi kepiting bakau adalah luas keramba, jumlah benih dan jumlah pakan. Sementara jumlah tenaga kerja secara statistik tidak signifikan berpengaruh terhadap produksi. Faktor-faktor internal pembudidaya yang diduga berpengaruh terhadap produksi adalah tingkat pendapatan responden, dimana tingkat pendapatan merupakan kemampuan pembudidaya dalam hal permodalan guna membiayai aktivitas produksi. Variabel internal yang lain seperti tingkat pendidikan dan usia responden secara statistik tidak signifikan. 


\section{DAFTAR PUSTAKA}

Anto Dajan, 1996. Pengantar Metode Statistik Jilid II, Jakarta : LP3S.

Arief, S., 1993. Metodologi Penelitian Ekonomi, Jakarta : UIPress.

Budi, S., \& Aslamsyah, S. (2011). Improvement of the Nutritional Value and Growth of Rotifer (Brachionus plicatilis) by Different Enrichment Period with Bacillus sp. Jurnal Akuakultur Indonesia, 10(1), 67-73.

Budi, S., \& Zainuddin, Z. (2012). Peningkatan Asam Lemakrotifer Brachionus Plicatilis Dengan Periode Pengkayaan Bakteri Bacillus Sp. Berbeda. Octopus: Jurnal Ilmu Perikanan, 1(1), 1-5.

Budi, S., Karim, M. Y., Trijuno, D. D., Nessa, M. N., Gunarto, G., \& Herlinah, H. (2016). The use of fatty acid omega-3 HUFA and Ecdyson Hormone To Improve Of Larval Stage Indeks and Survival Rate Of Mud Crab Scylla olivacea. Simposium Nasional Kelautan dan Perikanan, 3, 487-498.

Budi, S., Karim, M. Y., Trijuno, D. D., Nessa, M. N., Gunarto, G., \& Herlinah, H. (2016, August). Tingkat Dan Penyebab Mortalitas Larva Kepiting Bakau, Scylla spp. Di unit Pembenihan Kepiting Marana Kabupaten Maros. In Prosiding Forum Inovasi Teknologi Akuakultur (Vol. 1, No. 1, pp. 465-471).

Budi, S., Karim, M. Y., Trijuno, D. D., Nessa, M. N., \& Herlinah, H. (2018). Pengaruh Hormon Ecdyson Terhadap Sintasan Dan Periode Moulting Pada Larva Kepiting Bakau Scylla olivacea. Jurnal Riset Akuakultur, 12(4), 335-339.

Budi, S., Mardiana, M., Geris, G., \& Tantu, A. G. (2021). Perubahan warna ikan mas cyprinus carpio dengan penambahan ekstra buah pala myristica argentha pada dosis berbeda. Jurnal Ilmiah Ecosystem, 21(1), 202-207.

Cunningham, S. Mr. Dun and D Whitmars, 1985. Fisheries Economic and Introduction, Mansell Publishing ltd. London.

Departemen Pertanian, 1999, Penggemukan Kepiting Bakau (Scylla Serrata). Badan Penelitian dan Pengembangan Pertanian, Balai Pengkajian Teknologi Pertanian Ungaran.

Dewa Ketut SS., 1996. The Measurement of Total Factor Productivity Growth Using Production Frontier : A Case of Irrigated Rice Farming in Wes Java. JAE, Volume 15, Nomor 1, halaman $1-19$.

Direktorat Jenderal Perikanan, 2010, Statistik Perikanan. Departemen Pertanian Republik Indonesia.

Faidar, F., Budi, S., \& Indrawati, E. (2020). Analisis Pemberian Vitamin C Pada Rotifer dan Artemia Terhadap Sintasan, Rasio Rna/Dna, Kecepatan Metamorfosis Dan Ketahanan Stres Larva Rajungan (Portunus Pelagicus) Stadia Zoea. Journal of Aquaculture and Environment, 2(2), 30-34.

Gujarati, D., 2003. Basic Econometrics. Fourth Edition. International Edition. Singapore : Mc Graw-Hill.

Gunarto dan Adi Hanafi, 2000. Pengembangan Budidaya Ikan dan Kepiting Bakau dalam Kawasan Bakau, jurnal Litbang
Pertanian, Volume 19, No. 1, Halaman 33 - 39.

Gunarto, 2004. Konservasi Mangrove Sebagai Pendukung Sumber Hayati Perikanan Pantai, jurnal Litbang Pertanian, Volume 23, No. 1, Halaman 15 - 21.

Hasan Basri Tarmizi dan Gunawan Sumodiningrat, 1989, Pengaruh Penggunaan Faktor Produksi Terhadap Produksi, Pendapatan dan Distribusinya Pada Sawah Berpengairan dan Tanpa Pengairan, Berkala Penelitian Pasca Sarjana Universitas Gajah Mada (BPPS UGM), Jilid 2, No 2A, Edisi 1989, halaman $359 \sim 375$.

Herlambang. 2001. Ekonomi Makro : Teori Analisis dan Kebijakan, Jakarta : Gramedia.

Indah Susilowati, 2003, Analisis Ekonomi Alat Tangkap Trawl-Mini (Jaring Cothok). Studi Kasus di Kabupaten Pemalang Jawa Tengah, Media Ekonomi dan Bisnis, Vol. XV. No. 1 Juni 2003.

Indah Susilowati, Agung sudaryono, Tri Winarni A. 2004. Pengembangan Model Pemberdayaan Masyarakat Pesisir (Usaha Mikro, Kecil, Menengah dan Koperasi-UMKMK) dalam Mendukung Ketahanan Pangan di Kabupaten / Kota Pekalongan, Jawa Tengah. Lemlit UNDIP, Semarang

Jondrow, J., Lovell, C.A.K., Materov, I.S., and Schmid, P., (1982). On Estimation of Technical Inefficiency in The Stochastic Frontier Production Function Model. Journal of Econometrics, 19:233-236.

Kumbhakar, S.C. (1987), The Specification of Technical and Allocative Inefficiency in Stochastic Production and Profit Frontiers, Journal of Econometrics, 34 : 335-348.

Marsambuana Pirsan, A., 2001. Perbaikan Teknologi Perikanan Budidaya untuk Peningkatan Produktivitas Lahan Pesisir, Jurnal Litbang Pertanian, Volume 20, Nomor 3, halaman $84-97$.

Masri Singarimbun dan Sofian Effendi, 1989. Metodologi Penelitian Survey, Jakarta : Galia Indonesia.

Mimit Primyastanto, 1992. Efisiensi Usaha dan Alokasi Input Usaha Tani Tambak Udang Windu di Kabupaten Pasuruan Jawa Timur, Malang : Fakultas Perikanan Universitas Brawijaya.

Mohammad Noor, 2002. Bioeconomics of The Culture For Common Carp in Floating Net Cages in The Maninjau Lake West Sumatera, JEP, Volume 7, Nomor 1, Halaman $21-31$.

Mudrajad Kuncoro, 2002. Metode Kuantitatif, Teori dan Aplikasi untuk Bisnis dan Ekonomi, Edisi Pertama, Yogyakarta : Unit Penerbit dan Percetakan AMP YKPN.

Mudrajad Kuncoro, 2002. Otonomi dan Pembangunan Daerah, Jakarta : Penerbit Erlangga.

Nicholson W., 1995. Teori Mikro Ekonomi, Prinsip Dasar dan Perluasan. Edisi Kelima. Terjemahan : Daniel Wirajaya, Jakarta : Bina Rupa Aksara.

Nasir M., 1988. Metode Penelitian, Jakarta : Dhalia Indonesia. Panayotou, T., 1980. Production Technology on Economic Eficiency, A. Conceptual Frame Work Small Scale Fisheries in Asia, IDRC, Otawa - Canada.

Pindyek, Roberts dan Daniel L. Rubinfeld, 1995. Microeconomics, Prentice Hall International, Inc. 
Rokhmin Dahuri, Rais Ginting, Sitepu, 2001. Pengelolaan Sumberdaya Wilayah Pesisir dan Lautan Secara Terpadu, Jakarta : Pradaya Paramitha.

Sadono Sukirno, 2000. Pengantar Teori Mikro Ekonomi, Edisi Kedua, Jakarta : PT. Raja Grafindo Persada.

Salvatore, Dominic, 1995, Teori Mikro Ekonomi, Alih Bahasa : Rudy Sitompul, Edisi Kedua, Penerbit Erlangga, Jakarta.

Santoso, B. 1999, Pendugaan fungsi Keuntungan dan Skala Usaha pada Usahatani Kopi Rakyat di Lampung, Pusat Penelitian Agro Ekonomi, Bogor.

Sismadi, 2006. Analisis Efisiensi Penggunaan Input Alat Tangkap Purse Seine di Kota Pekalongan, Tesis S2, MIESP, UNDIP (tidak dipublikasikan) Soediyono Reksoprayitno, 2000, Pengantar Ekonomi Mikro Edisi Millenium, Yogyakarta-BPFE.

Soekartawi, 2003. Agribisnis, Teori dan Aplikasinya, Cetakan Ketujuh, Jakarta : PT. Raja Grafindo Persada

Soekartawi, 2003. Teori Ekonomi Produksi, dengan Pokok Bahasan Analisis Fungsi Cobb-Douglass, Cetakan Ketiga, Jakarta : PT. Raja Grafindo Persada.

Sufridson Iksan Semaoen, Hamid Hidayat dan Ahmad Sutarmadi, 1989, Effisiensi Ekonomi pada Usahatani Padi di Kalimantan Tengah, Berkala Penelitian Pasca Sarjana Universitas Gajah Mada (BPPS-UGM), jilid. 2 No. 3A, Edisi 1989, hlm. 639-650.

Sumaryanto, 2001. Estimasi Tingkat Efisiensi Usaha Tani Padi dengan Fungsi Produksi Frontier Stokastik, Jurnal Agro Ekonomi, Volume 19, No. 1, Halaman 65 - 84.

Susantun, I, 2000. Fungsi Keuntungan Cobb-Douglass dalam Pendugaan Efisiensi Ekonomi Relatif, Jurnal Ekonomi Pembangunan, Volume 5 No. 2, Halaman 149-161.

Yootopoulos, Pan A. dan Jeffrey B Nugent, 1976. Economic of Development, Empirical Investigation, Harper and Row Publishers.

Yusneri, A., Budi, S., \& Hadijah, H. (2020). Pengayaan Pakan Benih Rajungan (Portunus Pelagicus) Stadia Megalopa Melalui Pemberian Beta Karoten. Journal of Aquaculture and Environment, 2(2), 39-42.

Yusneri, A., \& Budi, S. (2021, May). Blue swimming crab (Portunus pelagicus) megalopa stage seed feed enrichment with beta carotene. In IOP Conference Series: Earth and Environmental Science (Vol. 763, No. 1, p. 012026). IOP Publishing.

Wahyuni, S., Budi, S., \& Mardiana, M. (2020). Pengaruh Shelter Berbeda Terhadap Pertumbuhan Dan Sintasan Crablet Kepiting Rajungan (Portunus pelagicus). Journal of Aquaculture and Environment, 3(1), 06-10.

Zen, LW., Abdullah., dan T.S Yew. 2003, Technical Efficiency of The Driftnet and Payang Seine (Lampara) Fisheries in West Sumatra, Indonesia, Journal of Asian Fisheries Scince, 15.p.97-106. 